\title{
Survival and Growth of Brazil-Nut Seedlings in Tree-Fall Gaps and Forest Understory
}

\author{
Jorge Santiago Garate-Quispe ${ }^{1}$ (1) 0000-0002-7494-2274 \\ Mishari Rolando Garcia Roca ${ }^{1}$ (D) 0000-0003-4055-2718 \\ Gabriel Alarcón Aguirre ${ }^{1}$ (1) 0000-0003-0816-9911
}

\begin{abstract}
This study aimed to evaluate the influence of canopy openness on the survival and growth of Bertholletia excelsa seedlings, through experimental plantings in tree-fall gaps and forest understory in Madre de Dios, Peru. Sixtyfour seedlings were planted within the experimental design, with eight repetitions each with four seedlings in two treatments of canopy openness. Basal diameter, height, and incidences of seedlings mortality and regrowth were evaluated for twelve months. Survivorship, and the annual increase in height and diameter were significantly higher in gaps than in the understory $(p<0.05)$. Regression analysis showed a direct and highly significant relation between canopy openness and diameter increment $\left(r^{2}=0.61\right)$, and between canopy openness and height increment $\left(r^{2}=0.34\right)$. Due to the greater performance and high survival rate of Brazil-nut seedlings in the tree-fall gaps, we recommend enrichment planting in the clearings of natural forests in Madre de Dios.
\end{abstract}

Keywords: Bertholletia excelsa Humb. \& Bonp., canopy openness, Madre de Dios, mortality.

\section{INTRODUCTION AND OBJECTIVES}

The harvest of non-timber forest products (NTFP) represent an important and promising source of income to millions of people worldwide (Ticktin, 2004; Vieira et al., 2017). The extraction of Brazil-nuts is one of the most economically important non-timber forest products in Amazonia (Guariguata et al., 2017; Peres et al., 2003; Schöngart et al., 2015; Zuidema, 2003), firmly established in the domestic market and export (Tonini et al., 2008a). The ecological consequence of NTFP extraction is an alteration of the natural regeneration rate (i.e., seedling survival and growth), limiting the reproduction of harvested individuals, thus affecting the structure and dynamics of Brazil-nut populations (Ticktin, 2004).

The current Brazil-nut collection areas in Peru cover an area of 2.5 million hectares and are mainly located in the region of Madre de Dios (Kalliola \& Flores, 2011). There, the seed-gathering represent an important source of income for immigrant and indigenous communities (Lawrence et al., 2005). There are several examples of species that were exploited without any ecological criteria or sustainability and that later entered the IUCN Red List of threatened species, such as the classic examples for Peru as cedar (Cedrela odorata) and bigleaf mahogany (Swietenia macrophylla) (Fernandez et al., 2012; Richardson \& Peres, 2016). Presently, the Brazil-nut is classified as vulnerable to extinction according to the IUCN Red List of Threatened Species (IUCN Red List, 2019; Paiva et al., 2011).

Brazil-nut trees (Bertholletia excelsa Humb. \& Blonp., Lecythidaceae) are widespread in Amazonian Upland Terra Firme Forests (Mori \& Prance, 1990; Schöngart et al., 2015). The tree is iconic of Amazonian forests, reaching up to $50 \mathrm{~m}$ in height and a diameter at breast height (DBH) of $>300 \mathrm{~cm}$ (Salomão, 2009; Scoles \& Gribel, 2011; Zuidema \& Boot, 2002).

Brazil-nut trees commonly grow in clusters or stands (Mori \& Prance, 1990; Peres \& Baider, 1997; Shepard \& Ramirez, 2011; Schöngart et al., 2015). The aggregated pattern of Brazil-nut groves has been linked to a mix of biophysical and anthropogenic causes (Rockwell et al., 2017; Scoles \& Gribel, 2012; Thomas et al., 2015), such as early establishment in natural canopy gaps (Mori \& Prance, 1990) and shortrange seed dispersal by scatter-hoarding caviomorph rodents (Haugaasen et al., 2012; Peres et al., 1997; Rockwell et al., 2017).

${ }^{1}$ Universidad Nacional Amazónica de Madre de Dios (UNAMAD), Puerto Maldonado, MD, Perú 
Agoutis are considered as one of the natural seed dispersers of $B$. excelsa, since they may gather and store seeds in middens (Haugaasen et al., 2010; Peres et al., 2003) that are later forgotten. The stored seeds may germinate, forming high-density stands (Peres \& Baider, 1997; Scoles \& Gribel, 2011). Likewise, human influence is very important, because high-density stands are more prevalent in management areas or near the human settlements (Guedes et al., 2014; Paiva et al., 2011; Scoles \& Gribel, 2011; 2015).

Several recent studies suggest that the high levels of harvest may affect the population structure of Brazil-nut trees, decreasing the recruitment rate of regeneration in their populations (Peres et al., 2003). Its conservation status is particularly related to the over-exploitation of Brazil-nut seeds (Paiva et al., 2011) and to deforestation (Kalliola \& Flores, 2011; Scoles et al., 2016), which compromise the regeneration of the over-exploited populations and reduces the Brazil-nut biogeographical range (Paiva et al., 2011).

The survival and growth of seedlings depend on treefall gaps to develop further (Myers et al., 2000). B. excelsa is considered to be a long-lived pioneer tree (Peres et al., 2003; Scoles \& Gribel, 2011), since the plants appear in gaps as if they were pioneer species, but remain in more advanced successional stages (Scoles \& Gribel, 2012). Some experimental studies suggest that the Brazil-nut has higher seedling growth rates in clearings than the forest understory (Peña-Claros et al. 2002; Myers et al. 2000; Scoles \& Gribel 2012; Scoles et al. 2016; Tonini et al. 2008b).

On the other hand, the high mortality rate of seedlings during the first year of establishment is probably due to the predation of the endosperm by terrestrial mammals (Scoles \& Gribel, 2012). This predation is the main cause of death during the transition between the two first phases of the life cycle, from seedlings to saplings (Cotta et al., 2008; D'Oliveira, 2000; Zuidema \& Boot, 2002). However, little is known about this stage of regeneration in the Peruvian Amazon, which involves the influence of light availability on seedling survival and growth. In Madre de Dios, few previous studies have been conducted, although the Brazilnut was well studied in the Brazilian and Bolivian Amazon. Our study will be important for the management of natural Brazil-nut populations and future enrichment plantations, since it provides important information on seedling growth and survival under natural conditions.

This study aimed to evaluate the survival and growth of Bertholletia excelsa seedlings established in experimental plantings in the tree-fall gaps and forest understory in Madre de Dios, Peru. This investigation differs from other studies in several ways: (1) no fertilizer was used; (2) no silvicultural treatments were performed to increase growth rates, as we wanted to evaluate these rates under natural environmental conditions; and (3) during the experiment, the evaluations were conducted in short intervals (monthly).

\section{MATERIALS AND METHODS}

\subsection{Study area}

This experiment was conducted in a homogeneous tropical rain-forest at Cribatamad - The Center for Reference and Interpretation of Biodiversity in High-Terrace Amazonian Forests $\left(12^{\circ} 28^{\prime} \mathrm{S}, 69^{\circ} 8^{\prime} \mathrm{O}\right)$ from the Universidad Nacional Amazonica de Madre de Dios (UNAMAD) located in Madre de Dios, southwestern Peruvian Amazon. Cribatamad is a forest research and training area for undergraduate students from the School of Forestry at UNAMAD (Alarcón \& Zevallos, 2011). The area consists of 428 ha of Terra Firme Forest (250 $\mathrm{m}$ a.s.l.). The vegetation is a forest remnant logged a few years ago, dominated by the arborescent palms Euterpe precatoria and Iriartea deltoidea, in which Apuleia leiocarpa, Clarisia racemosa, and Bertholletia excelsa are the emergent canopy trees. Nevertheless, B. excelsa is an exceptionally large emergent tree at Cribatamad, reaching 2-2.5 $\mathrm{m}$ in DBH (diameter at breast height), $35-45 \mathrm{~m}$ in height, and $35-50 \mathrm{~m}$ in crown diameter.

In Madre de Dios, the productive Brazil-nut stands ranges from 200 to $400 \mathrm{~m}$ a.s.l. Mean annual temperature annual rainfall (for 1980-2016) are $25.4^{\circ} \mathrm{C}$ and $2,120 \mathrm{~mm}$, respectively. Annual rainfall is irregular, ranging from $2,860 \mathrm{~mm}$ to $1,500 \mathrm{~mm}$, and it is not evenly distributed along the year. On average, $75 \%$ of the rainfall is concentrated between October and April and a dry season from June to August, when rainfall is less than $100 \mathrm{~mm}$ (Li et al., 2006).

\subsection{Experimental design}

In July 2011, sixty-four seedlings were planted within the experimental design in tree-fall gaps ( 32 seedlings) and forest understory sites (32 seedlings) at Cribatamad. Eight repetitions each were performed with four seedlings in two treatments of canopy openness: gaps (20-40\% canopy openness) and forest understory (8-10.5\% canopy openness). Before planting, the vegetation was removed in a $1 \mathrm{~m}$ diameter circle around the sites where the B. excelsa seedlings were planted. However, we did not use any fertilizer, and no maintenance was performed during the experiment. All Brazil-nut seedlings were nine months at the time of planting, with a mean height of $17.6 \pm 4.08 \mathrm{~cm}$ and basal diameter of $0.41 \pm 0.10 \mathrm{~cm}$. Height was measured from the soil surface to the shoot tip or the highest part of 
the seedling (Myers et al., 2000). Diameter and height were measured at the beginning of the experiment, then monthly for one year. Height was measured using a measuring tape, and basal diameter was measured using a Vernier. The rainfall data and monthly precipitation accumulated from 2011 to 2012 were obtained from the weather station of Puerto Maldonado ( $15 \mathrm{~km}$ from the study area), owned by Peruvian National Service of Meteorology and Hydrology (SENAMHI, 2016).

Canopy openness, length, and width of each leaf, incidences of seedlings mortality and regrowth were monitored during each seedling height and diameter monthly monitoring. The percentages of canopy openness were estimated using a spherical crown densitometer (Lemmon, 1956), to characterize the light environment in gaps and forest understory. Four estimates were made in the four compass directions at 1.30 height above ground (Lemmon, 1956), exactly above all Brazil-nut seedlings.

The leaf equation to estimate the leaf area of B. excelsa seedlings in this research was determined using 50 different sizes leaves $\left(\mathrm{n}=50\right.$, adjusted $\left.\mathrm{r}^{2}=0.989, p<0.001\right)$ (Equation 1$)$. The total leaf area for generating this equation was determined using the plug-in Toaster (Tree or planT Organs And STructures analiZER) available in the free software ImageJ 4.15 (Borianne, 2010; Schneider et al., 2012).

$\ln \mathrm{AF}=1.085 \ln (\mathrm{L})+1.049 * \ln (\mathrm{A})-0.758$

In which AF: total leaf area $\left(\mathrm{cm}^{2}\right)$; A: leaf width $(\mathrm{cm})$; and $\mathrm{L}$ : leaf length.

\subsection{Data analysis}

Initial differences in seedling height and basal diameter, and canopy openness were analyzed using one-sided $t$-test with tree-fall gaps and forest understory as factors. The $T$-student test was used to compare the annual average seedling survival. Also, the non-parametric Mann-Whitney $U$ test was used to analyze the differences in height, diameter, and seedling survival (4 months and 12 months), as they did not fit the assumptions of a parametric test.

The survival probability $(P s)$ of each seedling in gaps and understory were modeled using logistics regression models (Collet, 2003; Löf et al., 2007), using the Collet (2003) equation (Equation 2), in which the logistic transformation of $P s$ was expressed as a linear combination of two explanatory variables (treatment and time) $(x j, i)$ and treatment-time interaction, $\beta j$ are $k+1$ unknown parameters; $P s$ was estimated using GLM function of the R statistic in R-studio environment (R Core Team, 2016).

$$
\log \operatorname{it}\left(p_{s}\right)=\log \left(\frac{p_{i}}{1-p_{i}}\right)=\sum_{j=0}^{2} \beta_{j} X_{j, i}
$$

We tested for the effects of the canopy openness (\%) in tree-fall gaps and forest understory on survival, height growth, and basal diameter. Linear regression analysis was used to evaluate the relation between seedling height and diameter growth rates with canopy openness at 4 and 12 months. Seedling height was $\ln$-transformed before regression analysis to increase homoscedasticity (Peña-Claros et al., 2002). All the statistical analyses were performed using the $\mathrm{R}$ software ( $\mathrm{R}$ Core Team, 2016), and the figures were made using SigmaPlot 12.5 (Systat, 2013).

\section{3. RESULTS AND DISCUSSIONS}

\subsection{Canopy openness, diameter and height seedlings at the beginning of the experiment}

The application of two treatments resulted in different levels of canopy openness at the beginning of the experiment $(t$-test: $t=-9.5, p<0.001)$. In canopy gaps, the mean canopy openness was $29.5( \pm 11.5) \%$, while at the understory sites it was $9.7( \pm 2.6) \%$. The levels of canopy openness in the forest understory where smaller than previous studies in the Brazilian and Bolivian Amazon, although they were similar regarding the forest understory (Hayashida-Oliver et al., 2001; Peña-Claros et al., 2002; Scoles et al., 2011; 2014).

On the other hand, no significant differences were found between the initial diameter $(t$-test $=-0.11, p=0.90>0.05)$ and height $(t$-test $=0.16, p=0.87>0.05)$ of seedlings from the two treatments. The Brazil-nut seedlings used in our investigation were smaller than in other studies in the Amazonia (17.6 $\pm 4.08 \mathrm{~cm}$ height), including those by Hayashida-Oliver et al., 2001 (42 cm height), Scoles et al. (2011; 2014) (80-120 height), and Souza et al. (2017) $(49 \pm 7.3 \mathrm{~cm}$ height).

\subsection{Survival}

After 12 months, 34 B. excelsa seedlings died (53.1\% of all seedlings). Survival in the tree-fall gaps was significantly greater than in the forest understory $(t$-test: $\mathrm{t}=-4.7, p<0.001)$ (Figure 1 and Table 1), $75.0 \%$ and $18.8 \%$ respectively. Similar results were found by Peña-Claros et al. (2002) and Scoles et al. $(2011 ; 2014)$. The overall survival found in this study is lower than the one reported by Cornejo (2003) in a similar study conducted in old-growth forests in Madre de Dios, Peru (about $87 \%$ annual). This difference in survival was probably due to the silvicultural treatments applied by Cornejo (2003) 
(i.e., to remove of vegetation around the seedlings and for seedling protection). However, the seedling survival in treefall gaps (75\%) was higher than those found by Kainer et al. (1998) in Acre (Brazil), 12 months after planting $(<60 \%)$.

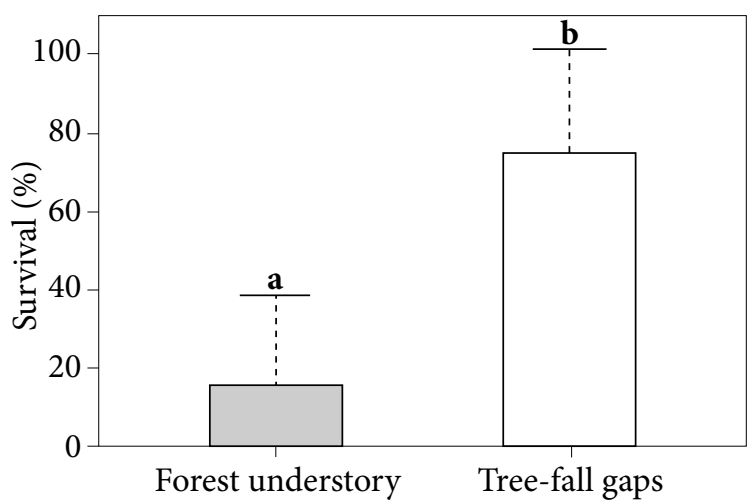

Figure 1. Survival of $B$. excelsa seedlings in the forest understory and tree-fall gaps. Bars represent the mean of seedlings survival. Means with a different letter above error bars are significantly different across treatment using t-student test $(p<0.05)$.

In this study, further analysis shows that seed-predators (Agoutis and others) caused $18.8 \%$ of mortality in gaps and $50 \%$ in the forest understory (Table 1). In these cases, the Brazil-nut seedlings were extracted from the hypocotyledon and often only the broken stems remained due to the extraction attempt. Similar observations were reported by Peña-Claros et al. (2002) in the Bolivian Amazon and by Cornejo (2003) in the Peruvian Amazon.

The highest mortality of seedlings occurred during the beginning of the rainy season, and when B. excelsa fruits began to fall (Figure 2). Peres et al. (1997) found similar results in his study when analyzing the Janzen-Connell model of seed escape to distance from parental trees using an experiment of seed removal in a primary forest of southeastern Pará, Brazil. This seasonal difference in mortality by predators seems to be related to phenology, fruit drop, and greater activity of its natural dispersers when fresh fruits and seeds remain in the soil (Peres et al., 2003). On the other hand, after germinating, the seed might be eaten by animals (Agoutis and others). Since the seed takes more than a year to be completely absorbed by the seedling (Cornejo, 2003), this is considered the main cause of predation.

The interaction between treatments and time was significant $(p<0.05)$ (Table 2). Thus, a simplified binomial model was used, removing the interaction to see if there was indeed a difference in survival of Brazil-nut seedlings between treefall gaps and understory (Figure 3). Treatments and treatment-time interaction were highly significant $(p<0.05)$, which shows a significant difference in the survival probability of $B$. excelsa seedlings between the forest understory (Figure $3 \mathrm{a}$ ) and treefall gaps (Figure $3 b)$. The proportion of variance explained by the Generalized Linear Model (deviance) was $\mathrm{D}^{2}=92 \%$.

Table 1. Number of Brazil-nut seedlings used by treatment and incidents throughout the study period at Cribatamad, Madre de Dios, Peru.

\begin{tabular}{lccccc} 
& & \multicolumn{3}{c}{ Mortality } & Regrowth \\
\cline { 3 - 5 } Treatment & $\mathbf{n}$ & $\begin{array}{c}\text { Seed- } \\
\text { predators }\end{array}$ & Dry & Overall & \\
\hline Tree-fall gaps & 32 & 6 & 2 & 8 & 2 \\
Understory & 32 & 16 & 10 & 26 & 4 \\
\hline Total & 64 & 22 & 12 & 34 & 6 \\
\hline
\end{tabular}

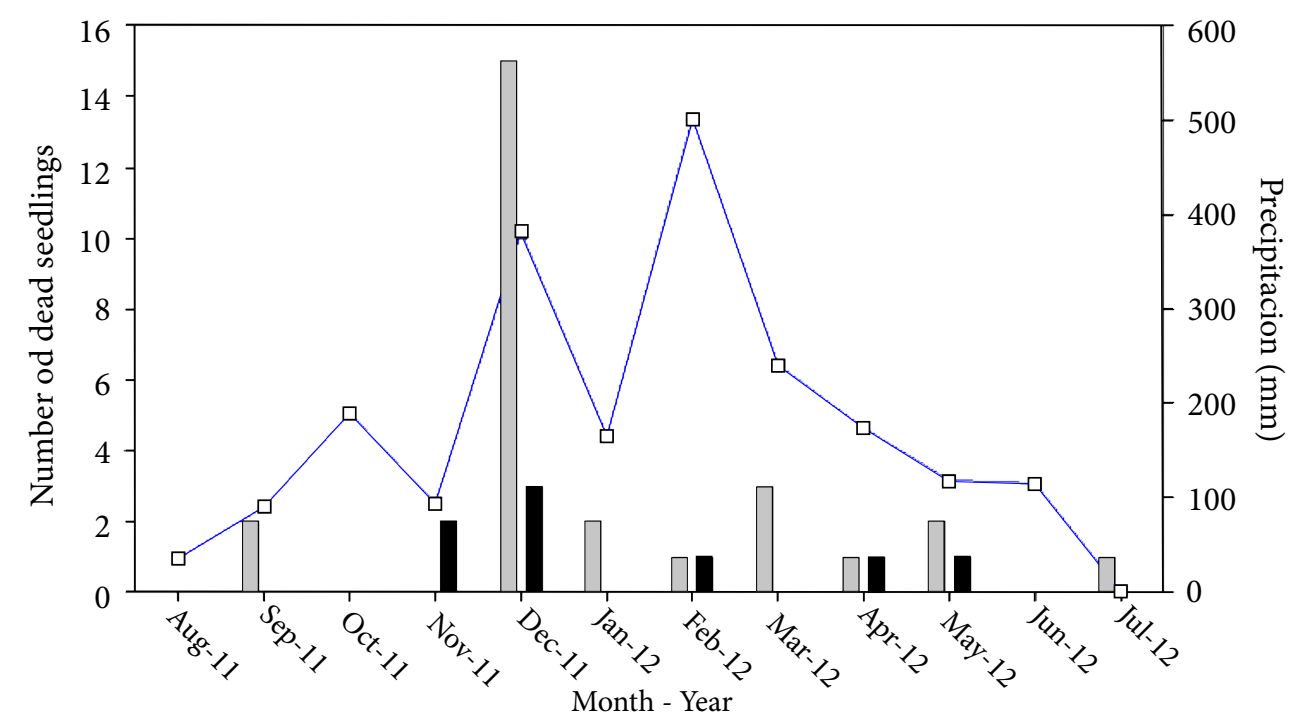

Figure 2. Sequence of mortality episodes of all Brazil-nut seedlings in tree-fall gaps (black bars) and forest understory (gray bars). The blue line represents the monthly precipitation accumulated in 2011-2012 (SENAMHI). 
Table 2. Logistic regression analyzed using generalized linear models (GLM) to estimate the probability of survival of Brazil-nut seedlings. Survival-time (months) and treatments (gaps and understory) were included as variables.

\begin{tabular}{|c|c|c|c|c|c|c|c|}
\hline & Coefficients & $\begin{array}{l}\text { Standard } \\
\text { error }\end{array}$ & Chi-squared & $p$ & $\begin{array}{c}\text { Null } \\
\text { deviance }\end{array}$ & $\begin{array}{l}\text { Residual } \\
\text { deviance }\end{array}$ & AIC \\
\hline (Intercept) & 6.85 & 0.55 & 12.51 & $<2 \times 10^{-16 * * *}$ & \multirow{3}{*}{346.60} & \multirow{3}{*}{27.20} & \multirow{3}{*}{100.70} \\
\hline Treatment & -2.30 & 0.21 & -10.76 & $<2 \times 10^{-16 * * *}$ & & & \\
\hline Time & -2.55 & 0.24 & -10.54 & $<2 \times 10^{-16 * * *}$ & & & \\
\hline
\end{tabular}

AIC: Akaike Information Criteria. Asterisks indicate significance at: ${ }^{\star} p<0.05 ;{ }^{* *} p<0.01 ;{ }^{* *} p<0.001$.

In this study, survival rates in the forest understory were lower than similar experiments on B. excelsa seedlings in the Amazon, such as the studies by Scoles et al. (2011) in Brazil (95\% after two years), and Peña-Claros et al. (2002) in an enrichment experiment in the Bolivian Amazon (86.5\% per year). However, it was similar to Scoles et al. (2014) in the Brazilian Amazon (21\% after 6 years). This is probably because we did not use protection against herbivores, no maintenance was performed during the experiment, and because of the small seedlings used (height $<20 \mathrm{~cm}$ ). Seedling mortality is low when the height is $>70 \mathrm{~cm}$.

\subsection{Regrowth}

During the 12 months of evaluation, 6 cases of regrowth (9.4\%) were identified in all seedlings of the experiment. The proportion of seedling regrowth after drying varied according to treatment. It was higher in the tree-fall gaps than in the understory, $100 \%$ and $50 \%$ respectively (Table 1). Opposite results were found by Scoles et al. $(2011,2014)$, who did not find significant differences in regrowth between the two environmental situations.

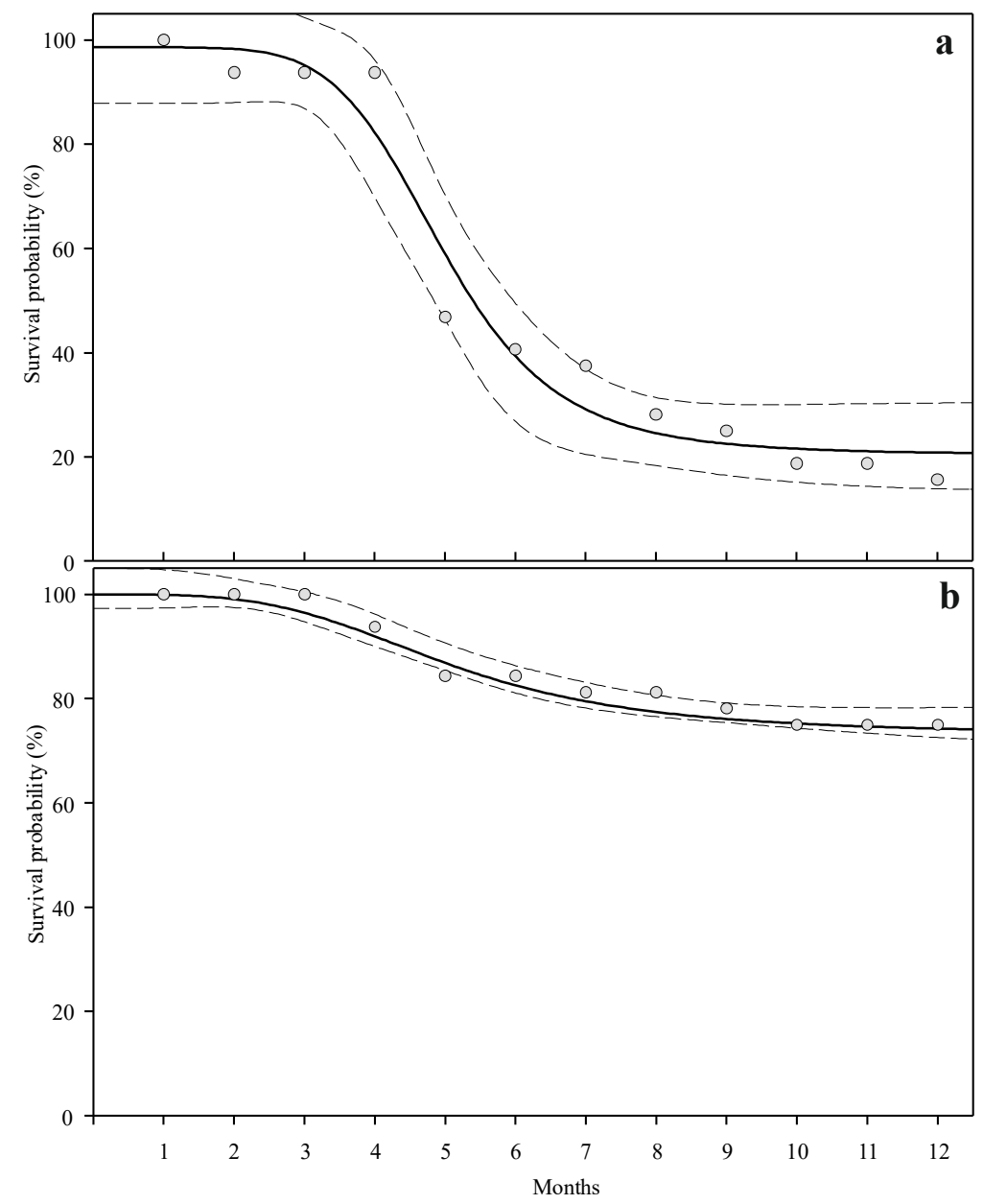

Figure 3. Predicted monthly and annual probability of survival for B. excelsa in forest understory (a) and tree-fall gaps (b). Filled dots are the observed proportions of survival of the seedlings in successive months. Broken lines are the pointwise asymptotic 95 percent confidence bands for the predicted values. 
In the forest understory, all the seedlings that regrew died a few months after the episode (3-4 months later). In the treefall gaps, $75 \%$ of the regrowing seedlings survived until the end of the experiment. Nevertheless, these seedlings grew slower compared to nearby seedlings. They had an increase in height between $17 \%$ to $32 \%$ less than the average of the seedlings in their corresponding repetition. The results of regrowth found in this study are different to those reported by Cornejo (2003) and Scoles et al. (2011; 2014), who found that, in most cases of regrowth, a favorable situation was created in height growth, increasing the rates of growth in the following months. This is probably due to the use of large seedlings (height $>80 \mathrm{~cm}$ ) by Scoles et al. $(2011 ; 2014)$.

\subsection{Height and diameter growth}

Four months after transplantation, mean height growth was higher and significantly different (Mann-Whitney test $U=72.5, p<0.001)$ in gaps $(10.5 \pm 9.4 \mathrm{~cm})$ than in understory $(1.9 \pm 2.2 \mathrm{~cm})$. Also, at the end of the experiment, Brazil-nut seedlings were significantly (Mann-Whitney $U=2$, $p=0.001)$ (Figure 4a) taller in gaps $(40.2 \pm 29 \mathrm{~cm})$ than in the understory $(3.3 \pm 2.4 \mathrm{~cm})$.

Four months after transplantation, mean basal diameter growth was higher and significantly different (MannWhitney test $U=163, p<0.001)$ in gaps $(1.1 \pm 0.5 \mathrm{~mm})$ than in the understory $(0.6 \pm 0.4 \mathrm{~mm})$. Also, 12 months later, Brazil-nut seedlings were significantly (Mann-Whitney $U=17, p=0.018$ ) (Figure 4a) taller in gaps $(3.6 \pm 2.2 \mathrm{~mm}$ ) than in the understory $(1.4 \pm 0.9 \mathrm{~mm})$.

Our results show that, in tree-fall gaps, the height increase was greater than in diameter, rising to $230 \%$ and $90 \%$ on average, respectively. The rapid increase in height would ensure their establishment and make them less susceptible to predation. It would be a strategy to reach the canopy faster and have more available light, then the growth in diameter would be more important to guarantee its establishment. The main reason for greater growth of Brazil-nut seedlings in tree-fall gaps is the high lightness, although Beckage \& Clark (2003) suggest that the presence of understory-gap interactions could influence the competitive seedling environment and the resource limitation on seedling growth and survival.

Similar results about the greater growth in tree-fall gaps than the understory were found in studies on the Brazilian, Bolivian and Peruvian Amazon (Bloemen \& Huiszoon, 1994; Cornejo, 2003; Hayashida-Oliver et al., 2001; Kainer et al., 1998; Myers et al., 2000; Peña-Claros et al., 2002; Scoles et al., 2011; 2014; Scoles \& Gribel, 2012; Van Rijsoort et al., 1993). Therefore, the microenvironmental conditions created due to the formation of natural gaps in the Tropical Rainforest might be potentially favorable for the survival of Brazilnut seedlings.
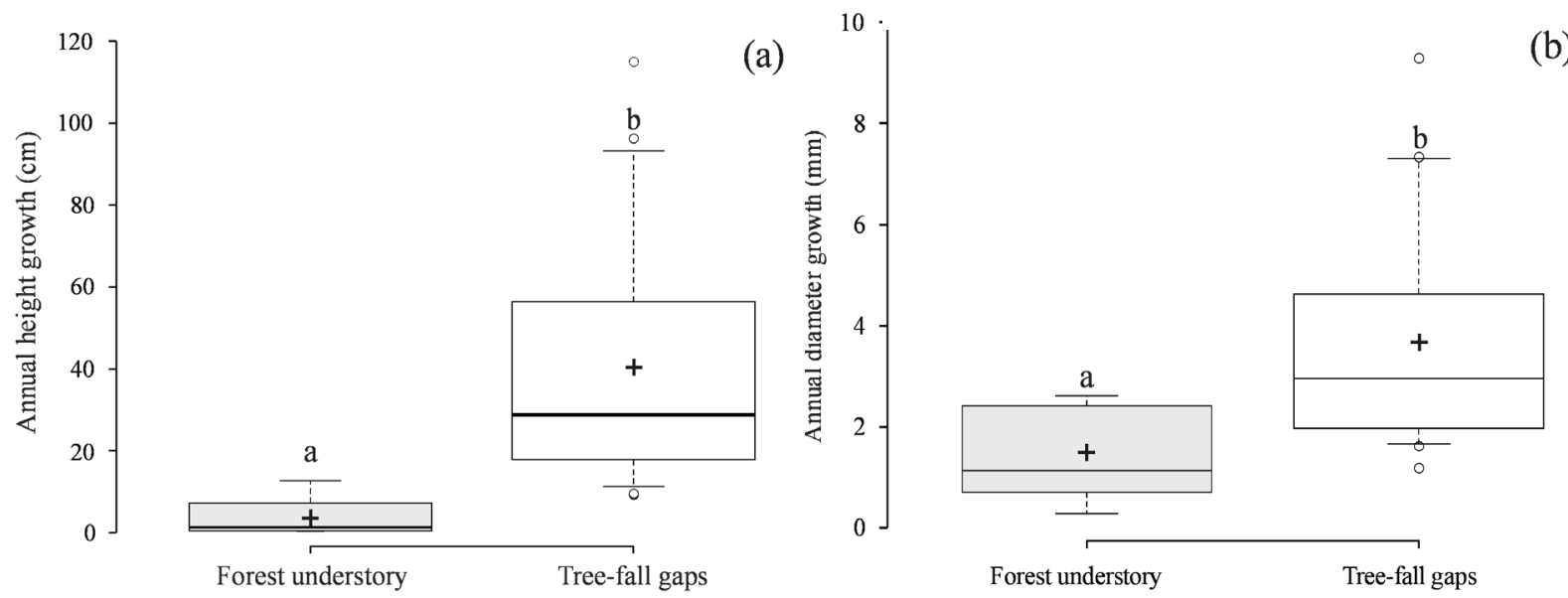

Figure 4. Box plot for comparison of the annual height growth (a) and annual diameter growth (b) between the forest understory and tree-fall gaps. Dots represent outliers; crosses represent sample means. Means with a different letter above the same boxplot are significantly different across treatment using the Mann-Whitney $U$-test $(p<0.05)$.

\subsection{Growth vs. Canopy openness}

Brazil-nut seedlings responded positively to canopy openness. In forest understory, diameter and height growth rate after four months did not have a significant linear relation with canopy openness $\left(p>0.05, \mathrm{r}^{2}=0.004\right)$. Due to the low number of Brazil-nut seedlings that died in 2012, it was not possible to adjust the linear relation after 12 months. Nevertheless, in tree-fall gaps, the diameter growth rate had a positive linear relation with the canopy openness after $4(p=0.024<0.05$, 
$\left.\mathrm{r}^{2}=0.18\right)$ and 12 months $\left(p<0.001, \mathrm{r}^{2}=0.61\right)$ (Figure 5). Also, in tree-fall gaps, the height growth rate had a positive linear relation with canopy openness after $4(p=0.004<0.01$, $\left.\mathrm{r}=0.52, \mathrm{r}^{2}=0.27\right)$ and 12 months $(p=0.004<0.01, \mathrm{r}=0.58$, $r^{2}=0.34$ ) (Figure 6).

The mean height growth of $40 \mathrm{~cm} /$ year found in this study is similar to those reported by Kainer et al. (1998) in Acre, Brazil and Cornejo (2003) in treefall gaps in Madre de Dios, Peru, when investigating the influence of canopy openness on survival and growth of Brazil-nut seedlings in a Primary Tropical Forest. Cornejo (2003) suggests that protection against herbivores and canopy gapping would significantly increase the growth of $B$. excelsa seedlings. The average diameter growth in the tree-fall gaps of our study $(3.6 \mathrm{~mm}$ ) was lower than those reported by Kainer et al. (1998) (3.85 mm) in Acre (Brazil).

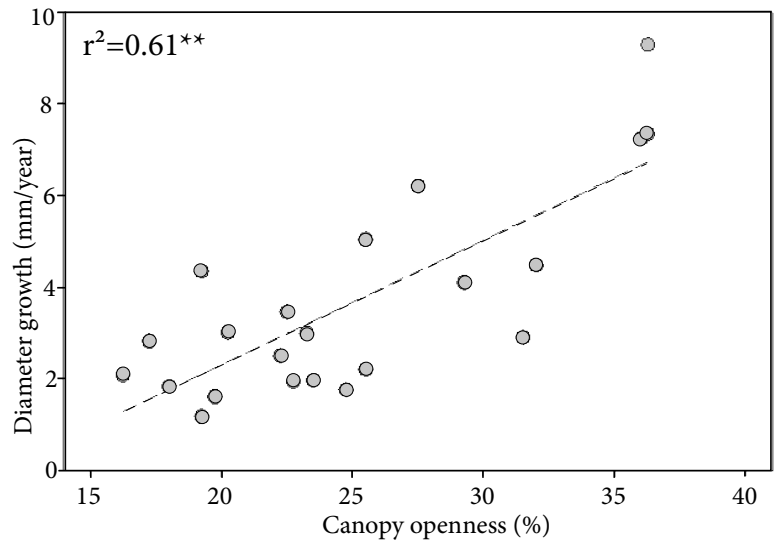

Figure 5. Relation between annual diameter growth and canopy openness on Brazil-nut seedling in tree-fall gaps. The equation is diameter growth $=0.272$ (Canopy openness) -3.134 .

Asterisks indicate significance at: ${ }^{*} p<0.05 ;{ }^{* *} p<0.01 ;{ }^{* * *} p<0.001$.

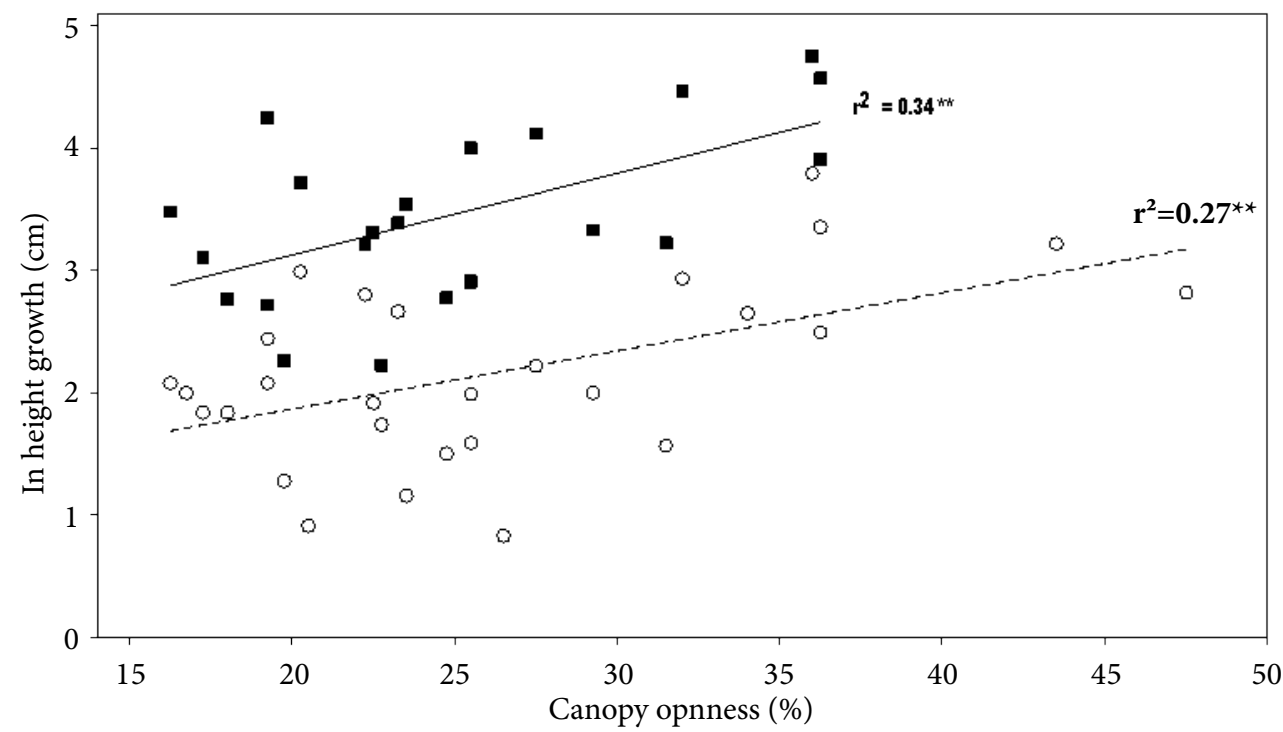

Figure 6. Relation between ln height growth (Hgr) rate and canopy openness on Brazil-nut seedling in tree-fall gaps, after four months (open circles) and after 12 months (closed squares). The equation for four months is $\ln (\mathrm{Hgr})=0.919+0.0475$ (canopy openness), and for 12 months is $\ln (\mathrm{Hgr})=1.798+0.0665$ (canopy openness).

Asterisks indicate significance at: ${ }^{*} p<0.05 ;{ }^{* *} p<0.01 ;{ }^{* * *} p<0.001$.

The results found in our study agree with those obtained by Myers et al. (2000), who consider the regeneration of B. excelsa as opportunistic and highly dependent on a "gap-dependent" canopy openness (Mori \& Prance 1990). Although seeds may germinate in the forest understory, they need higher light levels (heliophyta) for greater performance and higher survival (Myers et al., 2000; Peña-Claros et al., 2002; Scoles \& Gribel, 2011; Scoles et al., 2014). This result suggests that a disturbance in the canopy can be the most important factor in the survival and growth of
B. excelsa seedlings (Myers et al., 2000). In clearings, the light is abundant, the demand for nutrients and water by the rapidly growing seedlings is also higher, mainly due to higher respiration and photosynthetic rates in leaves (Chen et al., 2008). Likewise, Denslow et al. (1990) suggested that light availability is the most critical limiting factor for growth in tree-fall gaps (Myers et al., 2000), and luminosity is essential because Brazil-nut seedlings are light-demanding and depend on gaps in the forest to reach their reproductive size (Mori \& Prance, 1990; Paiva et al., 2011). 
Leaf shape and size differentiation were observed between Brazil-nut seedlings underplanted in the understory and tree-fall gaps. B. excelsa seedlings in the understory, unlike the tree-fall gaps, had small, thicker leaves, with serrated edges. This observation suggests that, due to the low light conditions of the understory (0-10\% canopy openness), it is expected that $B$. excelsa seedlings invest more available resources and biomass in their leaves to capture a greater amount of available light (Hayashida-Oliver et al., 2001; Poorter, 1999; Zuidema et al., 1999). This corroborates the results found by Hayashida-Oliver et al. (2001) and Boot (1994), who detected a higher proportion of leaf weight in seedlings of $B$. excelsa in understory than tree-fall gaps, while the increase in leaf area in gaps could represent a strategy adopted by $B$. excelsa seedlings to maximize the interception of sunlight and $\mathrm{CO}_{2}$ fixation (Ferreira et al., 2012; Santos et al., 2006).

Bloemen \& Huiszoon (1994) and Van Rijsoort et al. (1993) suggested that $B$. excelsa seedlings in understory would have a reduced net assimilation rate, using little energy in tissue synthesis (increase in height, diameter and leaf yield). Consequently, seedlings of B. excelsa in understory would be more vulnerable to seed predators and herbivores, and would not be able to survive in the dense forest understory for extended periods when their first reserves have been depleted (Myers et al., 2000; Van Rijsoort et al., 1993).

\section{CONCLUSIONS}

The average survivorship and growth of Bertholletia excelsa seedlings were higher in tree-fall gaps than in the forest understory. Seedling predation was an important factor for the seedling survivorship in the forest understory. Additionally, regrowing Bertholletia excelsa seedlings had lower growth in diameter and height.

Considering the low density of natural regeneration in the Brazil-nut stands of Madre de Dios, we suggest enrichment plantation in natural tree-fall gaps, considering: (1) that the highest seedlings mortality occur during the rainy season, (2) the use large tree-fall gaps with a high light availability conditions (Cornejo, 2003; Hayashida-Oliver et al., 2001) with a canopy openness between 25-50\% (Goodale et al., 2014; Hayashida-Oliver et al., 2001; Peña-Claros et al., 2002)., and (3) protection against herbivores and (4) use of large seedlings $(>70 \mathrm{~cm})$. Larger seedlings would need more time to adapt their morphology to changes in light conditions and smaller ones would be more susceptible to attack by ants (leaves), hypocotyledon and seed predation.

\section{ACKNOWLEDGEMENTS}

We would like to thank Clotilde Gonzales, Ramiro Canahuire, James Lipa and Oliver Surco for hours of dedicated field research help. We also thank Francisco Román-Dañobeytia for his review and comments on an earlier version of the manuscript, and two anonymous reviewers for constructive comments and valuable suggestions on the manuscript.

\section{SUBMISSION STATUS}

Received: 24 Nov. 2017

Accepted: 18 Aug. 2019

Associate editor: Henrique Machado Dias

(D) 0000-0003-2217-7846

\section{CORRESPONDENCE TO \\ Jorge Santiago Garate-Quispe}

Universidad Nacional Amazónica de Madre de Dios (UNAMAD), Av. Jorge Chávez, 1160, CP 17001, Puerto Maldonado, MD, Perú e-mail: jgarate@unamad.edu.pe

\section{REFERENCES}

Alarcón G, Zevallos P. Estructura y composición florística de un bosque de terraza baja en Tambopata, Madre de Dios. Biodiversidad Amazónica 2011; 3(3): 44-53.

Beckage B, Clark J. Seedling survival and growth of three forest tree species: the role of spatial heterogeneity. Ecology 2003; 84(7): 1849-1861.

Bloemen S, Huiszoon A. The morphology of Bertholletia excelsa seedlings and saplings in relation to light availability and ontogeny. Internal report No. 940525. Utrecht: Utrecht University; 1994.

Boot R. Growth and survival of tropical rain forest tree seedlings in forest understory and canopy openings Implications for forest management. Guyana: Tropenbos International, Utrecht University; 1994.

Borianne P. Tree and planT organs and structures analyzer L-Toaster v.2.2.2. How to get geometric parameters of Homogeneous Leaves from desktop scanner. Montpellier: AMAP-CIRAD; 2010.

Chen Y-J, Bongers F, Cao K-F, Cai Z. Above- and below-ground competition in high and low irradiance: tree seedling responses to a competing liana Byttneria grandifolia. Journal of Tropical Ecology 2008; 24(5): 517-524. 10.1017/S0266467408005233

Collet D. Modelling Binary Data. 2nd ed. London: Chapman \& Hall/CRC; 2003.

Cornejo F. Historia natural de la castaña y propuestas para su manejo. Puerto Maldonado: ACCA; 2003.

Cotta J, Kainer K, Wadt L, Staudhammer C. Shifting cultivation effects on Brazil nut (Bertholletia excelsa) regeneration. Forest Ecology and Management 2008; 256(1-2): 28-35. 10.1016/j.foreco.2008.03.026

D'Oliveira M. Artificial regeneration in gaps and skidding trails after mechanized forest exploitation in Acre, Brazil. Forest Ecology and Management 2000; 127(1-3): 67-76. 10.1016/S0378-1127(99)00117-6 
Denslow J, Schultz J, Vitousek P, Strain B. Growth responses of tropical shrubs to treefall gap environments. Ecology 1990; 71(1): 165-179. 10.2307/1940257

Fernandez F, Antunes P, Macedo L, Zucco C. How sustainable is the use of natural resources in Brazil? Natureza \& Conservação 2012; 10(1): 77-82. 10.4322/natcon.2012.013

Ferreira J, Gonçalves J, Ferraz J. Growth and water use efficiency of young brazil nut plants on degraded area subjected to fertilization. Ciência Florestal 2012; 22(2): 393-401. 10.5902/198050985747

Guedes M, Neves E, Rodrigues E, Paiva P, Costa J, Freitas M et al. "Castanha na roça": increasing yields and renewing Brazil nut stands through shifting cultivation in Amapá State, Brazil. Boletim do Museu Paraense Emílio Goeldi. Ciências Naturais 2014; 419(2): 381-398.

Goodale U, Berlyn G, Gregoire T, Tennakoon K, Ashton M. Differences in survival and growth among tropical rain forest pioneer tree seedlings in relation to canopy openness and herbivory. Biotropica 2014; 46(2): 183-193. 10.1111/btp.12088

Guariguata M, Cronkleton P, Duchelle A, Zuidema P. Revisiting the "cornerstone of Amazonian conservation": a socioecological assessment of Brazil nut exploitation. Biodiversity and Conservation 2017; 26(9): 2007-2027. 10.1007/s10531-017-1355-3

Haugaasen J, Haugaasen T, Peres C, Gribel R, Wegge P. Fruit removal and natural seed dispersal of the Brazil nut tree (Bertholletia excelsa) in Central Amazonia, Brazil. Biotropica 2012; 44(2): 1-5. 10.1111/j.1744-7429.2011.00796.x

Haugaasen J, Haugaasen T, Peres C, Gribel R, Wegge P. Seed dispersal of the Brazil nut tree (Bertholletia excelsa) by scatter-hoarding rodents in a central Amazonian forest. Journal of Tropical Ecology 2010; 26(3): 251-262. 10.1017/S0266467410000027

Hayashida-Oliver Y, Boot R, Poorter L. Effect of light and water availability on seedlings growth and morphology of Swietenia macrophylla, Cedrela odorata and Bertholletia excelsa. Ecología en Bolívia 2001; 35: 51-60.

IUCN Red List. The UICN Red List of Threatened Species: Bertholletia excelsa [Internet]. 2019 [cited 2017 June 15]. Available from: https://bit.ly/2OPVfs8

Kainer K, Duryea M, Costa N, Williams K. Brazil nut seedling establishment and autecology in extractive reserves of Acre, Brazil. Ecological Applications 1998; 8(2): 397-410.

Kalliola R, Flores P. Brazil nut harvesting in Peruvian Amazonia from the perspective of ecosystem services. Fennia 2011; 189(2): 1-13.

Lawrence A, Phillips O, Ismodes A, Lopez M, Rose S, Wood D et al. Local values for harvested forest plants in Madre de Dios, Peru: Towards a more contextualized interpretation of quantitative ethnobotanical data. Biodiversity and Conservation 2005; 14(1): 45-79. 10.1007/s10531-005-4050-8

Lemmon R. A spherical densiometer for estimating forest overstory density. Forestry Science 1956; 2(4): 314-320. 10.1093/ forestscience/2.4.314

Li W, Fu R, Dickinson R. Rainfall and its seasonality over the Amazon in the 21 st century as assessed by the coupled models for the IPCC AR4. Journal of Geophysical Research Atmospheres 2006; 111(2): 1-14. 10.1029/2005JD006355
Löf M, Karlsson M, Sonesson K, Welander T, Collet C. Growth and mortality in underplanted tree seedlings in response to variations in canopy closure of Norway spruce stands. Forestry 2007; 80(4): 371-384. 10.1093/forestry/cpm022

Mori SA, Prance GT. Taxonomy, ecology, and economic botany of the Brazil nut (Bertholletia excelsa Humb. \& Bonpl. Lecythidaceae). Advances in Economic Botany 1990; 8: 130-150.

Myers G, Newton A, Melgarejo O. The influence of canopy gap size on natural regeneration of Brazil nut (Bertholletia excelsa) in Bolivia. Forest Ecology and Management 2000; 127(1-3): 119-128. 10.1016/S0378-1127(99)00124-3

Paiva P, Guedes M, Funi C. Brazil nut conservation through shifting cultivation. Forest Ecology and Management 2011; 261(3): 508-514. 10.1016/j.foreco.2010.11.001

Peres C, Baider C. Seed dispersal, spatial distribution and population structure of Brazil-nut trees (Bertholletia excelsa) in southeastern Amazonia. Journal of Tropical Ecology 1997; 13(4): 595-616. 10.1017/ S0266467400010749

Peres C, Baider C, Zuidema P, Wadt L, Kainer L, Gomes-Silva D et al. Demographic threats to the sustainability of Brazil nut exploitation. Science 2003; 302(5653): 2112-2114. 10.1126/science.1091698

Peres C, Schiesari L, Dias-Leme C. Vertebrate predation of Brazilnuts (Bertholletia excelsa, Lecythidaceae), an agouti-dispersed Amazonian seed crop: a test of the escape hypothesis. Journal of Tropical Ecology 1997; 13(1): 69-79. 10.1017/S0266467400010269

Peña-Claros M, Boot R, Dorado-Lora J, Zonta A. Enrichment planting of Bertholletia excelsa in secondary forest in the Bolivian Amazon: Effect of Cutting line width on survival, growth and crown traits. Forest Ecology and Management 2002; 161(1-3): 159-168. 10.1016/S0378-1127(01)00491-1

Poorter L. Growth responses of 15 rain-forest tree species to a light gradient; the relative importance of morphological and physiological traits. Functional Ecology 1999; 13(3): 396-410. 10.1046/j.13652435.1999.00332.x

R Core Team. $R$ : A language and environment for statistical computing [Internet]. Vienna: R Foundation for Statistical Computing; 2016 [cited 2016 May 3]. Available from: https://bit.ly/35KMy9n

Richardson V, Peres C. Temporal decay in timber species composition and value in amazonian logging concessions. PLOS ONE 2016; 11(7): 1-22. 10.1371/journal.pone.0159035

Rockwell C, Guariguata M, Menton M, Quispe E, Quaedvlieg J, Warren-Thomas E et al. Spatial distribution of Bertholletia excelsa in selectively logged forests of the Peruvian Amazon. Journal of Tropical Ecology 2017; 33(2): 114-127. 10.1017/S0266467416000614

Salomão R. Densidade, estrutura e distribuição espacial de castanheira-do-brasil (Bertholletia excelsa H. \& B.) em dois platôs de floresta ombrófila densa na Amazônia setentrional brasileira. Boletim do Museu Paraense Emílio Goeldi 2009; 4(1): 11-25.

Santos U, Gonçalves JFDC, Feldpausch TR. Growth, leaf nutrient concentration and photosynthetic nutrient use efficiency in tropical tree species planted in degraded areas in central Amazonia. Forest Ecology and Management 2006; 226(1-3): 299-309. 10.1016/j. foreco.2006.01.042 
Schneider C, Rasband W, Eliceiri K. NIH Image to ImageJ: 25 years of image analysis. Nature Methods 2012; 9(7): 671-675.

Schöngart J, Gribel R, Fonseca S, Haugaasen T. Age and growth patterns of Brazil nut trees (Bertholletia excelsa Bonpl.) in Amazonia, Brazil. Biotropica 2015; 47(5): 550-558. 10.1111/btp.12243

Scoles R, Canto M, Almeida R, Vieira D. Sobrevivência e frutificação de Bertholletia excelsa Bonpl. em áreas desmatadas em Oriximiná, Pará. Floresta e Ambiente 2016; 23(4): 555-564. 10.1590/21798087.132015

Scoles R, Gribel R, Klein G. Growth and survival of Brazil nuts (Bertholletia excelsa Bonpl.), in different environmental conditions in region River Trombetas, Oriximiná, Pará, Brazil. Boletim do Museu Paraense Emílio Goeldi 2011; 6(3): 273-293.

Scoles R, Gribel R. Population structure of Brazil Nut (Bertholletia excelsa, Lecythidaceae) stands in two areas with different occupation histories in the Brazilian Amazon. Human Ecology 2011; 39(4): 455-464. 10.1007/s10745-011-9412-0

Scoles R, Gribel R. The regeneration of Brazil nut trees in relation to nut harvest intensity in the Trombetas River Valley of Northern Amazonia, Brazil. Forest Ecology and Management 2012; 265: 71-81. $10.1016 /$ j.foreco.2011.10.027

Scoles R, Gribel R. Human influence on the regeneration of the Brazil nut tree (Bertholletia excelsa Bonpl., Lecythidaceae) at Capanã Grande Lake, Manicoré, Amazonas, Brazil. Human Ecology 2015; 43(6): 843-854. 10.1007/s10745-015-9795-4

Scoles R, Klein G, Gribel R. Performance and survival of Brazil nut tree (Bertholletia excelsa Bonpl., Lecythidaceae), in different light conditions after six years to planting, in Trombetas River region, Oriximiná, Pará, Brazil. Boletim do Museu Paraense Emílio Goeldi. Ciências Naturais 2014; 9(2): 321-336.

Servicio Nacional de Meteorología e Hidrología del Perú SENAMHI. Datos históricos de Meteorología e Hidrología [Internet]. 2016 [cited 2016 May 3] Available from: https://bit.ly/34ybAIP

Shepard G, Ramirez H. "Made in Brazil": human dispersal of the Brazil nut (Bertholletia excelsa, Lecythidaceae) in ancient Amazonia. Economic Botany 2011; 65(1): 44-65. 10.1007/s12231-011-9151-6
Souza C, Santos V, Ferreira M, Gonçalves J. Biomass, growth and ecophysiological responses of young plants of Bertholletia excelsa Bonpl. Subjected to different levels of irradiance. Ciência Florestal 2017; 27(2): 557-569. 10.5902/1980509827736

Systat. SigmaPlot 12.5 user's guide. San Jose: Systat Software; 2013.

Thomas E, Alcázar C, McMichael C, Corvera R, Loo J. Uncovering spatial patterns in the natural and human history of Brazil nut (Bertholletia excelsa) across the Amazon Basin. Journal of Biogeography 2015; 42(8): 1367-1382. 10.1111/jbi.12540

Ticktin T. The ecological implications of harvesting non-timber forest products. Journal of Applied Ecology 2004; 41(1): 11-21. 10.1111/j.1365-2664.2004.00859.x

Tonini H, Oliveira M, Schwengber D. Growth of amazon native species submitted to the plantation in the roraima state. Ciencia Florestal 2008a; 18(2): 151-158. 10.5902/19805098453

Tonini H, Kaminski P, Costa P. Relationship of Brazil-nut seed yield to crown morphometric characteristics and competition indexes. Pesquisa Agropecuária Brasileira 2008b; 43(11): 1509-1516. 10.1590/ S0100-204X2008001100009

Van Rijsoort J, Ugueto S, Zuidema P. Intensities, the Brazil nut tree (Bertholletia excelsa): population structures in tropical rain forest and growth response of seedlings to different light. Internal report No. 930405. Utrecht: Utrecht University; 1993.

Vieira D, Oliveira M, Gama J, Machado E, GØrgens E. Spatial pattern and sampling methods for Brazil nut tree in the mesoregion of the Lower Amazon, state of Para, Brazil Diego. Bosque 2017; 38(1): 97-107. 10.4067/S0717-92002017000100011

Zuidema P. Serie Científica Nro. 6: Ecología y manejo del árbol de Castaña (Bertholletia excelsa). Utrecht: Universidad de Utrecht; 2003.

Zuidema P, Dijkman W, Van Rijsoort J. Light and size dependent growth of seedlings of the Brazil nut tree (Bertholletia excelsa). Ecologia en Bolivia 1999; 33: 23-35.

Zuidema P, Boot R. Demography of the Brazil nut tree (Bertholletia excelsa) in the Bolivian Amazon: impact of seed extraction on recruitment and population dynamics. Journal of Tropical Ecology 2002; 18(1): 1-31. 10.1017/S0266467402002018 